DOI: https://doi.org/10.18371/fp.3(35).2019.190167

JEL Classification E44, G21

\title{
STATE BANKS AND THE REAL ECONOMY: CONTEMPORARY PROBLEMS AND PROSPECTS OF LENDING
}

\author{
KOSTOHRYZ Viktoriya \\ PhD in Economics, \\ Associate Professor of the Department of Finance and Banking, \\ Banking University, Cherkasy Institute \\ ORCID ID: https://orcid.org/0000-0002-8378-5549 \\ e-mail:kostogryzvg@gmail.com
}

\section{ZAPOROZHETS Svitlana}

PhD in Economics,

Associate Professor of the Department of Finance and Banking, Banking University, Cherkasy Institute ORCID ID: https://orcid.org/0000-0001-6947-0826 e-mail: zaporozhets11svitlana@ukr.net

\begin{abstract}
The article explores current features of bank lending to the real economy, clarifies the main problems that constrain financing of the real sector through banking institutions. An analysis of the ownership structure of assets and liabilities of the banking system has been carried out, and it has been determined that banks with the participation of public capital have sufficient resource, strategic and administrative potential and should play the role of financial channels of penetration of public policy (financial, monetary, investment) into the real economy. It has been found that in the current conditions of reforming the banking system of Ukraine, political and economic instability in the state, banks with the participation of state capital have a number of problems that can be overcome by implementing administrative and economic measures of macroeconomic and microeconomic character.
\end{abstract}

Keywords: state bank, bank lending, financial result, real economy
Аннотация. $B$ cmaтье исследованы современные особенности банковского кредитования реального сектора экономики, выяснены основные проблемы, сдерживающие финансирование реального сектора через банковские учреждения. Проведен анализ структуры собственности активов и обязательств банковской системы и определено, что банки с участием государственного капитала имеют достаточный ресурсный, стратегический и административный потенциал и должны выполнять роль финансовых каналов проникновения государственнической политики в реальный сектор экономики . Установлено, что в современных условиях реформирования банковской системы Украины, банки с участием государственного капитала имеют ряд проблем, которые возможно преодолеть с помощью внедрения административно-правовых $u$ экономических мер макроэкономического и микроэкономического характера.

Ключевые слова: государственный банк, банковское кредитование, финансовый результат, реальньіи сектор экономики. 
Formulation of the problem. In the current economic environment, banking institutions play an important role in stimulating the reproduction processes and financing the further development of the real economy. In the face of increased political and economic instability, unprofitable activity and bankruptcy of many banks of Ukraine, it is important to find segments of the banking market that have sufficient resource, strategic and administrative potential to provide financial resources for the reproductive processes of the real sector of economy.

Therefore, in the current situation, it is of particular relevance to study today's features of bank lending to the real economy, find out the main problems that constrain the financing of the real sector through banking institutions, and identify the ability of state banks to provide the necessary amounts of financing.

Analysis of recent research and publications. The availability of scientific publications exploring theoretical and practical aspects of bank lending to the real economy demonstrates relevance and importance of the subject. In particular, the works of N. Zhukov, S. Reverchuk, O. Solodka, O. Vasyurenko, V. Mishchenko, A. Moroz, M. Savluk, O. Lavrushin, and D. Kovalenko are concerned with the impact of credit on the development of the real economy. In particular, in O. Irshak's writings [1], the relationship between the volume of loans granted and the GDP of the state has been assessed. In the studies of $\mathrm{Y}$. Zhezherun, O. Bartosh [2], the relationship between the volume of credits granted, the level of bank liquidity and the financial results of the activity of domestic enterprises has been identified.

The theoretical and practical principles of state participation in the capital of commercial banks are widely explored in domestic literature. The issues of activity of state banks in Ukraine were addressed by such scientists as V. Onishchenko, N. Sheludko, O. Dzublyuk, L. Strelbytska, V. Stelmakh, M. Suganyak. In particular, the works of V. Onishchenko [3] investigated the tendencies of credit and deposit activity of state-owned banks. However, in the light of current global trends and instability of the domestic economy, it is necessary to consider key aspects of cooperation between stateowned banks and enterprises in the real economy in order to intensify the financing of reproduction processes.

Scientific purpose of this paper is to research current peculiarities of banking crediting and to systemize the preconditions of the renewal of state banks ability to emit credit resources for satisfying the agents' of the real sector demands.

Description of the main research material. The real economy, where significant added value is created, is the basis for the competitiveness of the national economy. The dominant characteristics of the economic development of the state depend on the parameters of its development and functioning.

A key condition for the effective functioning of business entities is their level of profitability. Overall, the financial performance of enterprises in the real economy in 2016-2018 was positive and in the three years increased by UAH 263.5 billion. At the same time, 
for many companies, the dynamics of financial results had negative trends. In particular, in agriculture, forestry and fisheries, the financial result for 20162018 decreased by UAH 23196 million, including $31.5 \%$ in 2017 , and $2 \%$ in 2018. Due to fixed assets revaluation by Ukrtransgaz and provision for bad receivables, the financial result of the transport industry decreased by 3.2 times in 2017 , and by 1.33 times in 2018. [4]

Researchers believe that an insufficient percentage of profitable enterprises is a negative factor in the development of the real economy sector (Fig. 1). By type of economic activity at the end of 2018, only agriculture, forestry and fisheries (87\%), construction $(81 \%)$ and light industry $(80 \%)$ had a significant percentage of profitable enterprises.

An important key to the development of the real economy is the additional financing of its core business processes, including financing through bank lending. In modern conditions, sources of financing businesses in Ukraine include own funds, bank loans, budgetary funds.

The current stage of development of the banking system of Ukraine is characterized by significant influence of political and economic factors that have led to significant structural changes. The 2014-2016 period is marked by a decrease in the number of banking institutions by 84 units or by $53.3 \%$. During 2017-2018, the decline in the number of banks slowed slightly and the difference from the previous years was 19 banking institutions. As of January 1 , 2019, 77 banking institutions were licensed by the National Bank of Ukraine. [5]

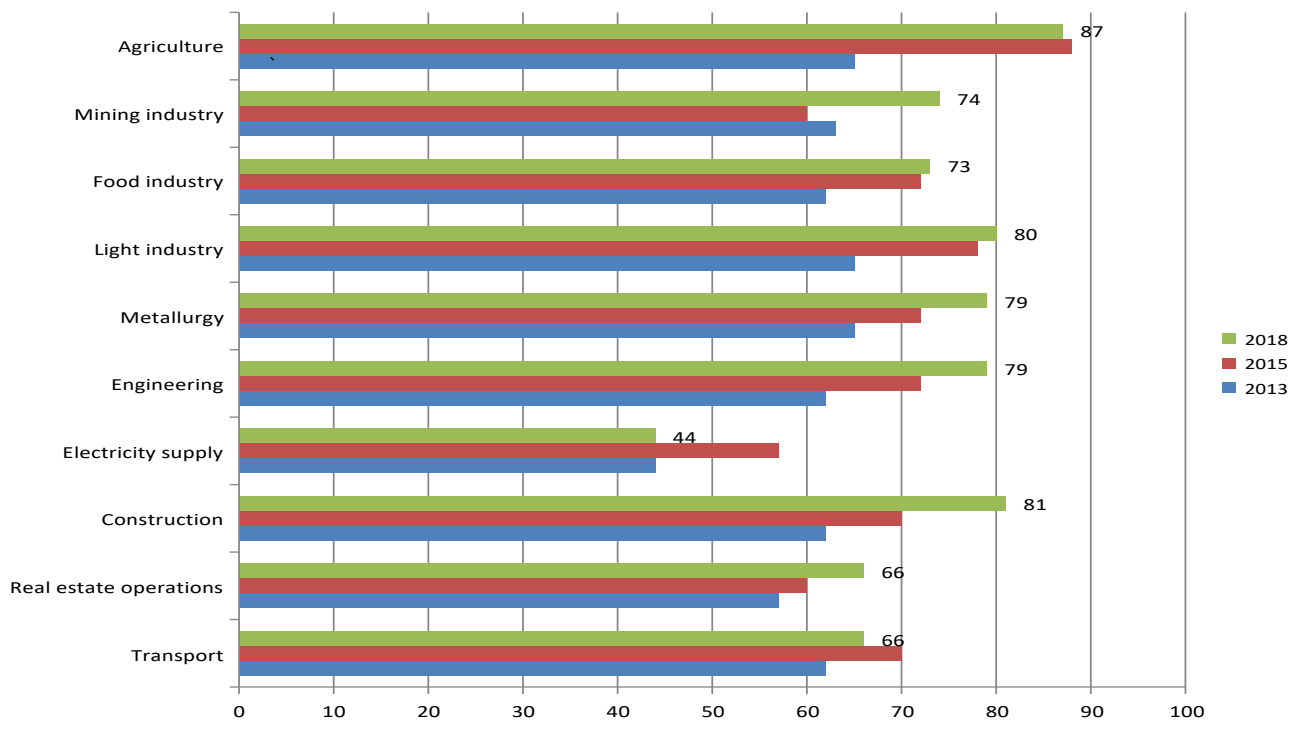

Figure 1. The share of profitable enterprises on the financial result before tax during 2013-2018, \%

Source: [4]

Despite the high GDP growth, the analyzed period, GDP grew by $49 \%$, dynamics of lending to customers by while the volume of loans increased by banking institutions was insignificant for the period 2016-2018. (Fig. 2) During the only $11 \%$. Therefore, we can conclude that the activity of Ukrainian banks in 
ensuring the rate of economic growth is very low . At the end of 2018, the ratio of loans to GDP, that is financial deepening, was less than $50 \%$, far below that figure for other countries, for example, Denmark - 180\%, Japan - 187\%, Eurozone countries (on average) - above $100 \%$, in countries with the highest incomes - above $150 \%$ [6].

During 2015-2018, loans to nonfinancial corporations outstripped those of households, but did not have a steady upward trend. After the decrease in the volume of loans to the real economy in
2016 by $1.7 \%$, during 2017-2018, the volumes of these loans increased by $4.5 \%$ to the amount of UAH 859.740 million at the beginning of 2019. [NBU] The downward trend in the development of bank lending to business entities is that loans were provided mainly for short-term and working capital financing. Loans to the real economy for up to 1 year amounted to $37.22 \%$ at the beginning of $2017,42.77 \%$ at the beginning of 2018 , and $48.11 \%$ at the beginning of 2019 .

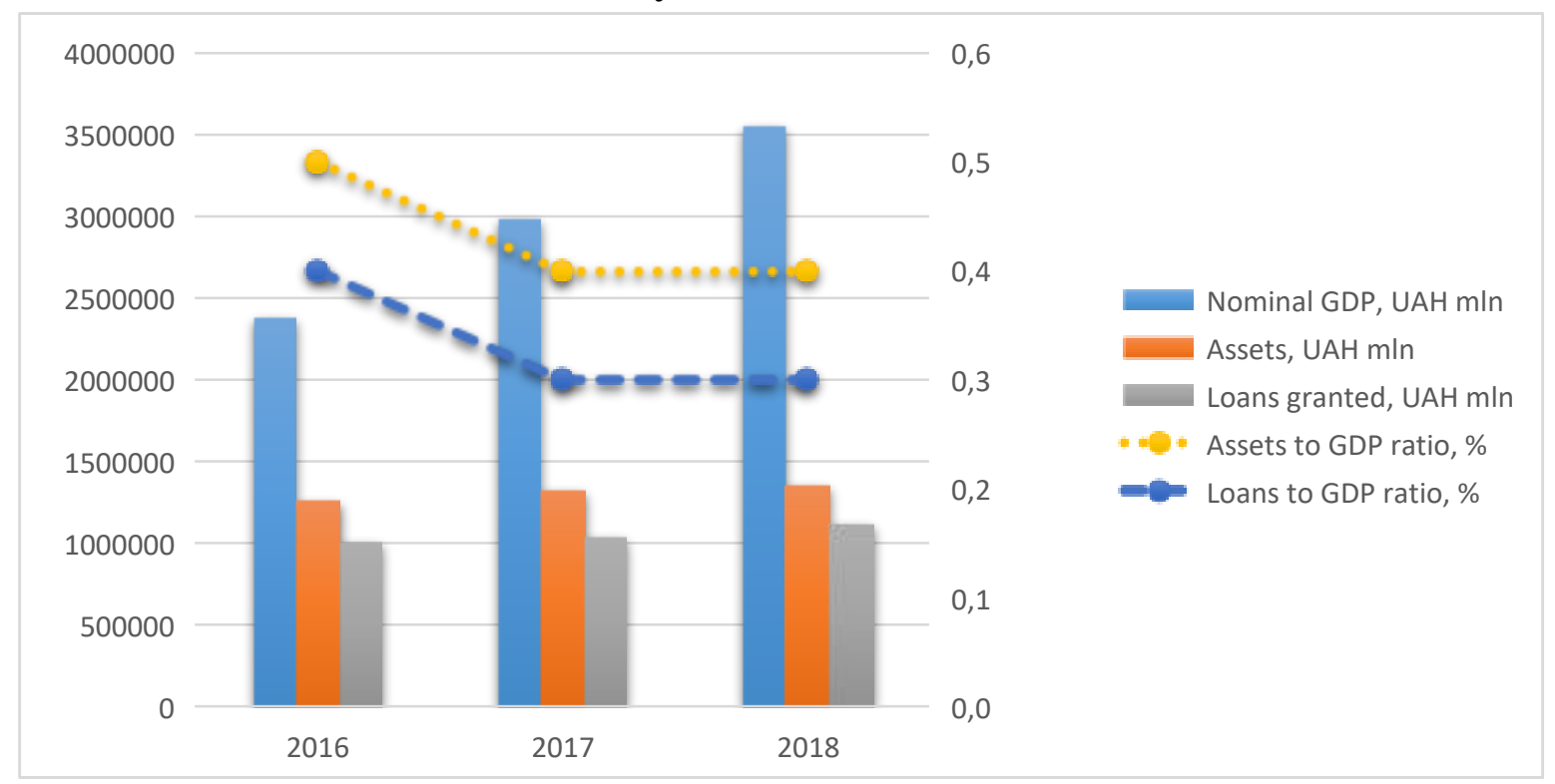

Figure 2. Dynamics of key performance indicators of banking institutions in comparison with GDP dynamics for the period 2016-2018

Source: generated by the authors based on [5]

In addition, the NBU estimates that the top 5 bank debtors, which are representatives of large corporate businesses, account for 39\% of banks' loan portfolio; accordingly, for 10 debtors it is $60 \%$ of the loan portfolio; for 20 debtors - $82 \%$ of the loan portfolio; for 40 debtors - $97 \%$ of the loan portfolio (UAH 255 billion in total), which indicates a significant concentration of banks' loan and investment activity on the business structures of related parties, etc. [7].

Foreign experience shows that in the face of significant financial problems of private domestic banking institutions, low lending to key sectors of economy, stability and development of the banking sector is based on state-owned banks. The state share in the banking sector of 
Germany is quite significant, accounting for more than $50 \%$ of all assets of the banking system and about $20 \%$ of the total number of German banks. The increase in the amount of state capital in the German banking system was made to maintain the banking system in times of crisis. [8].

Also noteworthy is the fact that in the period 2016-2018, private banks with domestic commercial capital became insolvent and their number decreased by 89 units during this period. The number of banks with state-owned capital remained constant. At the same time, despite the decrease in numbers, the percentage of the number of banks with foreign capital in the banking system of Ukraine has only increased (due to the rapid decrease in the number of domestic banks), accounting for $35 \%$ at the beginning of $2016,39 \%$ at the beginning of 2017 , and $46 \%$ at beginning of 2018 .

As a result of the transfer of JSC CB "PrivatBank" to one hundred percent state ownership, the share of banks with state share in the ownership structure of assets and liabilities of the banking system of Ukraine has increased significantly. In particular, at the beginning of 2017, the liabilities held by state-owned banks amounted to 55\%, which is 25 p.p. more than the previous year (Fig. 3, a). During 2017-2018, no significant structural changes took place and as of January 1, 2019 state-owned banks held $57 \%$ of the liabilities of banking institutions, which indicates the high resource potential of these financial institutions.

The volume of assets of state-owned banks during this period also increased significantly, and as of January 1, 2017 in the total ownership structure of assets of banking institutions it amounted to $52 \%$, which is by 24 p.p. more than at the beginning of 2016, and at the beginning of 2018 it was $56 \%$, which is 4 p.p. more than at the beginning of 2017. (Fig. 3, b). However, during 2018, as a result of a decrease in the percentage of state-owned banks' assets and an increase in the assets of banks with foreign capital, a structural redistribution of components took place, and as of January 1, 2019, $40 \%$ of assets of all banking institutions of the country are owned by state-owned banks, and $41 \%$ are owned by banks with foreign capital. This is a negative trend and it poses a threat of risks arising from the entry of large amounts of foreign capital into the banking system of the country. At the same time, by the end of 2018, the net financial assets and deposits of the general government market accounted for $54.7 \%$ and $63.4 \%$, respectively.

Government programs for financial stimulation of economic entities in the real economy are implemented by the Government of Ukraine mainly through banks with state-owned capital. In particular, such state banks as JSC CB "PrivatBank", JSC "Oschadbank", JSC "Ukrgasbank" and JSC "Ukreximbank" are participants in state compensation programs for agro-industrial enterprises, for which the state compensates part of the interest rate or loan amount. JSC "Ukreximbank" and the Ministry of Agricultural Policy of Ukraine have signed a Memorandum on the procedure of using the funds provided in the state budget to support the livestock industry. 


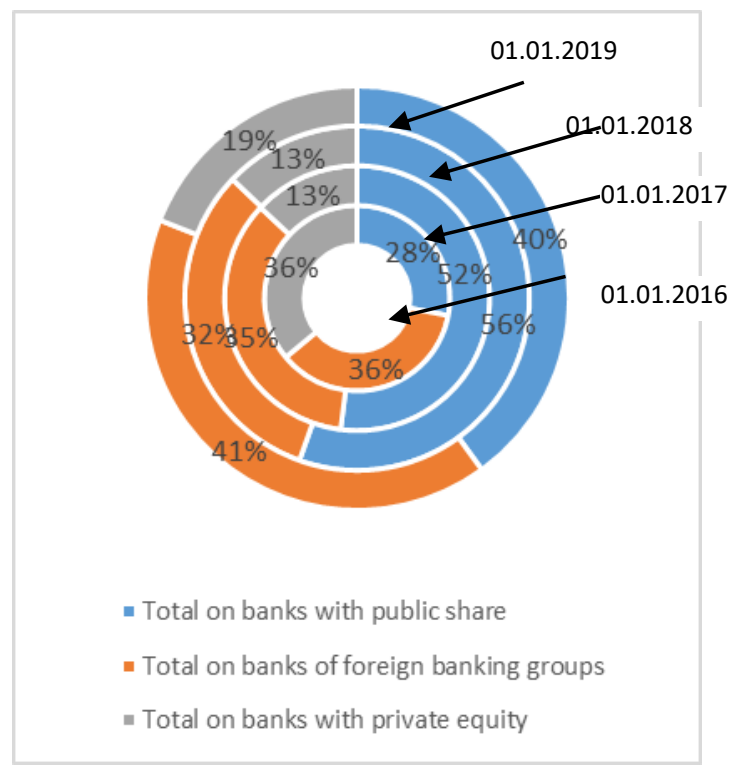

a) ownership structure of assets

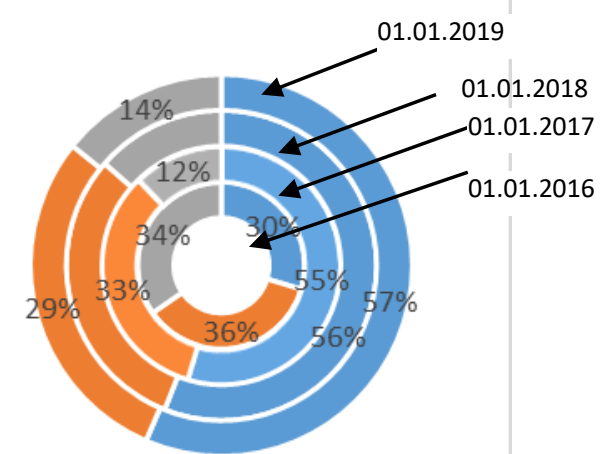

- Total on banks with public share

- Total on banks of foreign banking groups

- Total on banks with private equity

Figure 3. Structure of ownership of assets and liabilities of the banking system of

Ukraine for the period 2016-2018

Source: generated by the authors based on [5]

Thus, in the context of increasing the volume of lending to the real economy, state banks have sufficient resource, strategic and administrative capacity and have the role of financial channels of public policy (financial, monetary, investment, budget) penetration into the real economy.

However, among the four groups of banks, according to the NBU classification, as of January 1, 2018, the largest share of non-performing loans was owned by state-owned banks, namely $71.1 \%$ (in particular, PrivatBank had $87.6 \%$ and banks with state participation without PrivatBank had 55.7\%), foreign banks accounted for $41 \%$, and private equity banks accounted for $24 \%$. At the same time, as of December 1, 2018 , the share of non-performing loans in state-owned banks decreased to $68.1 \%$ (55.4\% for banks with state participation without PrivatBank), although the largest portion of non-performing loans remains at PrivatBank, namely $83.2 \%$ (decreased by $4.4 \%$ compared to the beginning of the year). [9]

In modern conditions, banks with the participation of the state capital have sufficient resource and administrative potential to financially stimulate the development of the real economy, but they have a number of problems that hinder this process, namely:

- large volume of non-performing loans in the credit portfolio of stateowned banks;

- government guarantees often induce bank managers to use insufficiently effective methods of managing a bank with significant risks [10];

- imperfection of the current legislation on specific features of state banks activity in the financial market;

- in the conditions of political and economic instability in the state, a considerable volume of assets of state- 
owned banks contributes to inefficient use of budgetary funds and development of corruption;

- the existence of politically motivated lending and related-party lending, which causes a significant concentration of bank lending and investing activities on the affiliates' business structures, etc .;

- low level of corporate governance of state-owned banks.

Administrative and legal and economic measures of macroeconomic and microeconomic character should be the main ways that can overcome most of these problems and improve the efficiency of government banking institutions, and have a positive impact on providing the real sector with the necessary financial resources. Their implementation should ensure saturation of the state economy with national financial resources, reorientation of public policy to long-term planning, and promote greater public confidence in financial institutions. The main ones are:

1.Creation of a mechanism for refinancing state-owned banks to further allocate these funds to enterprises in the real sector of economy. The key principle for implementing the structural refinancing mechanism should become depending of the volume and value of loans granted to commercial banks by $\mathrm{NBU}$, on the volume and quality of loans provided by banks to the real economy enterprises.

2. Reforming state-owned banks by raising corporate governance standards through the implementation of privatesector best practices, followed by their partial privatization.
3. Taking into account the specifics of functioning of state-owned banks, it is advisable to create an appropriate system of economic standards and financial indicators that would allow the most adequate assessment of their performance.

4. Creation of a state-owned asset management company that should accumulate non-performing loans from state-owned banks. This will allow to "clear" the balance sheets of working banks, to "unload" their credit and legal units from claim work and mortgage property of risky borrowers and to enable them to focus on lending activity. [11]

5. The legislative framework, in particular the Law of Ukraine "On Banks and Banking", should be supplemented with articles that would provide for a clearer and more complete regulation of the basic principles common to all public financial institutions. Article 57 of this Law states that "Deposits of individuals of the State Savings Bank of Ukraine are guaranteed by the state". However, there is a need to adopt by-laws to regulate mechanisms of payment of individual deposits in the event of bankruptcy of state-owned banks.

6. Restriction of the sale of government securities to banks (both government debt obligations, and NBU certificates) and a significant decrease in their profitability in order to intensify corporate lending by banks.

7. Partial commercialization of stateowned banks by selling up to $50 \%$ of their capital to outside investors, that may provide additional budgetary revenues. Involvement of top managers delegated by external investors to the governing bodies of state banks in 
proportion to their participation in the capital.

Conclusion. Current lending to business entities in the real economy does not provide the required volumes of effective activity. State-owned banks potentially have sufficient resource, strategic and administrative capacity to stimulate the development of the real economy and fulfill the role of financial channels of public policy penetration.
However, in the current conditions of reforming the banking system of Ukraine, political and economic instability in the state, banks with the participation of state capital have a number of problems that can be overcome through the introduction of administrative and economic measures of macroeconomic and microeconomic character.

\section{References}

1. Irshak, O. S. \& Leshchuk, I. Ya. (2018). Suchasnyi stan kredytnoi diialnosti bankiv ta yii vplyv na rozvytok realnoho sektoru ekonomiky [The current state of bank lending and its impact on the development of the real economy]. Prychornomorski ekonomichni studii - Prychornomor Economic Studies, 34, 145-149 [in Ukrainian].

2. Zhezherun, Yu.V. \& Bartosh, O.M. (2017). Perspektyvy vidnovlennia bankivskoho kredytuvannia realnoho sektoru ekonomiky [Prospects for the resumption of bank lending to the real economy]. Finansovi doslidzhennia - Financial research, 1(2), 144-152 [in Ukrainian].

3. Onishchenko, V.V. (2012). Analiz diialnosti derzhavnykh bankiv v Ukraini [Analysis of the activity of state-owned banks in Ukraine]. Visnyk SumDU - SSU Bulletin, 2, 186-192 [in Ukrainian].

4. Ofitsiinyi sait Derzhavnoi sluzhby statystyky Ukrainy [Official site of the State Statistics Service of Ukraine]. Retrieved from: http://www.ukrstat.gov.ua/.

5. Ofitsiinyi sait Natsionalnoho banku Ukrainy [Official site of the National Bank of Ukraine]. Retrieved from: https://bank.gov.ua/.

6. Rybalka, S. Vidnovyty kredytuvannia [Resume lending]. Retrieved from: https: http://agropolit.com/blog/86-vidnoviti-kredituvannya [in Ukrainian].

7. Rozhkova, K. Vyrishennia problemy NPL $\mathrm{v}$ bankivskii systemi Ukrainy. [Solving the NPL problem in the Ukrainian banking system]. Retrieved from: https://uff.icu/images/presentations/2017/Rozhkova-NBU_Presentation_on_NPLs_ UkrFinForum17.pdf [in Ukrainian]. 
8. Reverchuk, O. S. (2009). Svitovyi dosvid rozvytku derzhavnoho rehuliuvannia bankivskoho sektoru ta perspektyvy yoho zastosuvannia v Ukraini [World experience in the development of state regulation of the banking sector and prospects for its application in Ukraine]. Optymizatsiia rehuliatornoi polityky u bankivskomu i strakhovomu biznesi - Optimization of regulatory policy in banking and insurance business. Lviv: Liha pres, Triada plius [in Ukrainian].

9. Ohorodnyk, V. V. (2019). Problemni kredyty bankiv z derzhavnoiu uchastiu v Ukraini (suchasnyi stan ta prychyny vynyknennia) [Problem loans to state-owned banks in Ukraine (current state and causes)], Naukovyi visnyk Uzhhorodskoho natsionalnoho universytetu - Scientific Bulletin of Uzhgorod National University, 23(2), 38-43 [in Ukrainian] .

10. Kostohryz, V. H. \& Khutorna, M.E. (2018). Derzhavni banky u systemi zabezpechennia finansovoi stabilnosti bankivskoho sektoru Ukrainy [State banks in the system of ensuring the financial stability of the banking sector of Ukraine], Naukovyi visnyk Uzhhorodskoho universytetu - Uzhgorod University Scientific Bulletin, 1, 335-341 [in Ukrainian] .

11. Yurkiv, N.Ia. \& Hladkykh, D.M. Rozvytok bankivskoho kredytuvannia hospodariuiuchykh subiektiv yak umova zabezpechennia staloho ekonomichnoho zrostannia v Ukraini [Smooth Development of Bank Lending to Business Entities as a Condition for Sustainable Economic Growth in Ukraine]. Retrieved from: https://niss.gov.ua/doslidzhennya/ekonomika/rozvitok-bankivskogo-kredituvannyagospodaryuyuchikh-subektiv-yak-umova. 